\title{
Comparison of Lower and Middle Riphean sparry magnesite deposits of the Southern Urals province
}

\author{
MIKHAIL T. KRUPENIN \\ Institute of Geology and Geochemistry, Urals Brunch of RAS, Per. Pochtovy, 7, Yekaterinburg, \\ 620151, Russia. krupenin@igg.uran.ru
}

(Received November 2002 Accepted December 2002)

\begin{abstract}
Sparry magnesite deposits (SMD) of the Lower Riphean (LR) and Middle Riphean (MR)

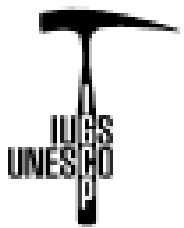
sequences in the western slope of the South Urals have some distinguished peculiarities, which allows to compare them and speculate about the mechanism of ore formation and Mg-source origin. LR magnesites are located in some stratigraphic levels and lie within widespread dolostone horizons. MR magnesites that occur in the lower carbonate member of Avzyan fm. are represented by dolomitized limestones. The shape of LR magnesite body is very often layer-like with sharp contacts. The shape of MR one is sometimes lens like, contacts of ore body are complecated with zones of impregnable magnesites near the hosting dolomites. The crystalline structures of LR magnesites are typically corse-grained with average size of crystalls $10 \mathrm{~mm}$. The magnesite grains of the MR one have 1-3 mm of average size. The chemical composition of MR magnesite ore shows increase of $\mathrm{SiO}_{2}, \mathrm{Al}_{2} \mathrm{O}_{3}, \mathrm{FeO}$ and decrease of LREE fractionation in comparison with the LR magnesites. As we assume, metasomatic magnesites of the Lower Riphean time are connected with sedimentation/early diagenesis stage. The source of $\mathrm{Mg}^{2+}$ came from a crust of weathering of basic and ultramafic rocks in humid climate. Magnesite occurrences in Middle Riphean time are connected with high Fe-contents metasomatic fluids, which were resulted of evaporite Mg-enriched solutions transformation during kathagenesis.
\end{abstract}

Key words: Riphean, Upper Precambrian, Urals, sparry magnesite, dolomite, breinerite, metasomatic fluids, diagenesis, burial epigenesis

\section{Introduction}

The South Urals sparry magnesite province of Riphean age consists of several ore districts, which contain ore groups and some single sparry magnesite deposits (SMD) and occurences. There are the following districts for Lower Riphean (LR) sequence: Bakal-Satka, Surunzyak, Ismakaevo and for Middle Riphean (MR) sequence: Zlatoust, Beloretsk, Katav, Kuzha (Fig. 1). Satka deposit is one of largest in the province with geological reserves about $300 \mathrm{Mt}$ of good quality magnesite. Only this deposit is the place of refractory production in modern time. Annual output of "Kombinat Magnesit" enterprise is 2,4 Mt of raw magnesite and $600 \mathrm{Kt}$ of periclase powder and different refractory wares. Other SMD are not used now, because they have conditions a bit worse than the Satka group. In XX century, predominantly during the World wars, such SMD as Katav-Ivanovsk (reserves is about 0,4 Mt), Kyzyltash (16 Mt), Aznalin (1,9 Mt) were exploited. In previous times several SMD were explored in different degree: Semibrtskoe (375 Mt), Ismakaevo (115 Mt), Balyatur (15 Mt), Egorova Polyana (0.15 Mt).

Geological conditions and features of LR and MR magnesites have some distinguished peculiarities, which allow comparing them and speculating about mechanism of ore formation and $\mathrm{Mg}$-source origin. This investigation based on geological study and mineralogical-geochemical data is carried out in the Institute of Geology and Geochemistry (Yekaterinburg), Technical University (Berlin), GeoForschungZentrum (Potsdam). 


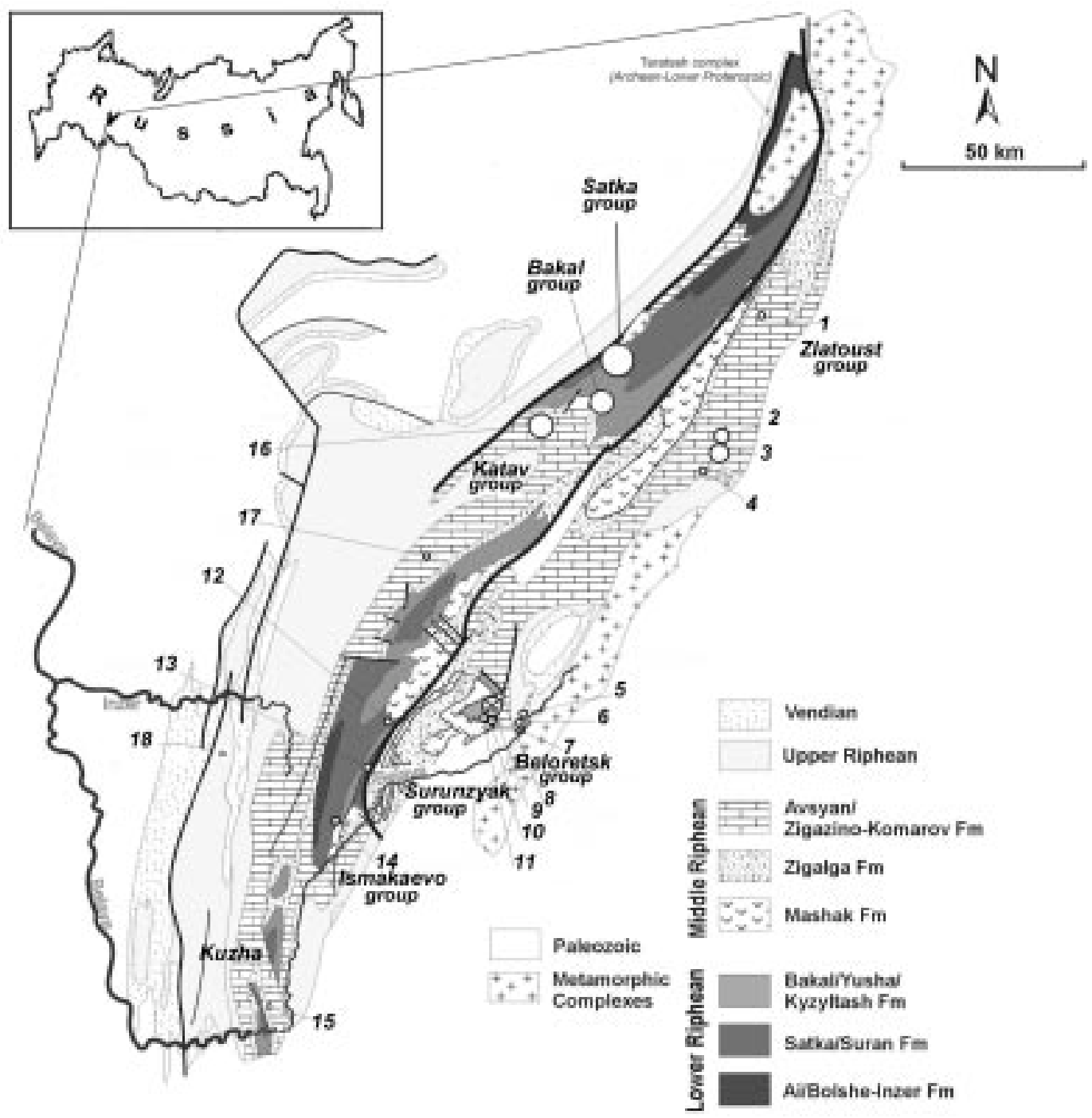

Fig. 1. Schematic geological map of Bashkirian mega-anticline. Magnesite occurrences: 1 - Zlatoust; 2 Veselovskoe; 3 - Semibratskoe; 4 - Khutor; 5 - Kataika; 6 - Otnurok; 7 - Egorova Polyana; 8 - Aznalin; 9 Kyzyltash; 10 - Yandyk; 11 - Belyatur; 12 - Yusha; 13 - Kardon; 14 - Ismakaevo; 15 - Yaru; 16 - KatavIvanovsk; 17 - Baygaza; 18 - Saryhka (borehole).

\section{Geological setting}

The province occurs to the stratotype place of the Riphean sequence. It is located in the Bashkirian megaanticline (BMA) - a folded and thrusted megastructure in the western slope of the South Urals. Size of this structure is about $300 \times 100 \mathrm{~km}$. There are three stratigraphic series: Lower (interval of age 1650-1350 Ma), Middle (1350-1050) and Upper Riphean (1050$650)$ with general thickness of sequence of $15 \mathrm{~km}$ (Semikhatov 1991). These series consist of terrigenous rocks (conglomerates, arkose and quartz sandstones, shales) in the lower part and clay-carbonate rocks (shales, limestones, dolostones) in the upper part. LR and MR series contain volcanic rocks in the base (basalts, liparites). The Riphean sequence was deposited in a shallow sedimentary basin in the eastern part of East European platform (Ufa-Gozhan aulacogen). There are unconformities and erosion of underlying the stratigraphic units in the base of the series. As the majority of lithological and geochemical indicators show, during Lower and the part of Middle Riphean time these sedimentary basins existed in humid climate, while in Upper Riphean time - predominantly in arid 
$\mathbf{S}$
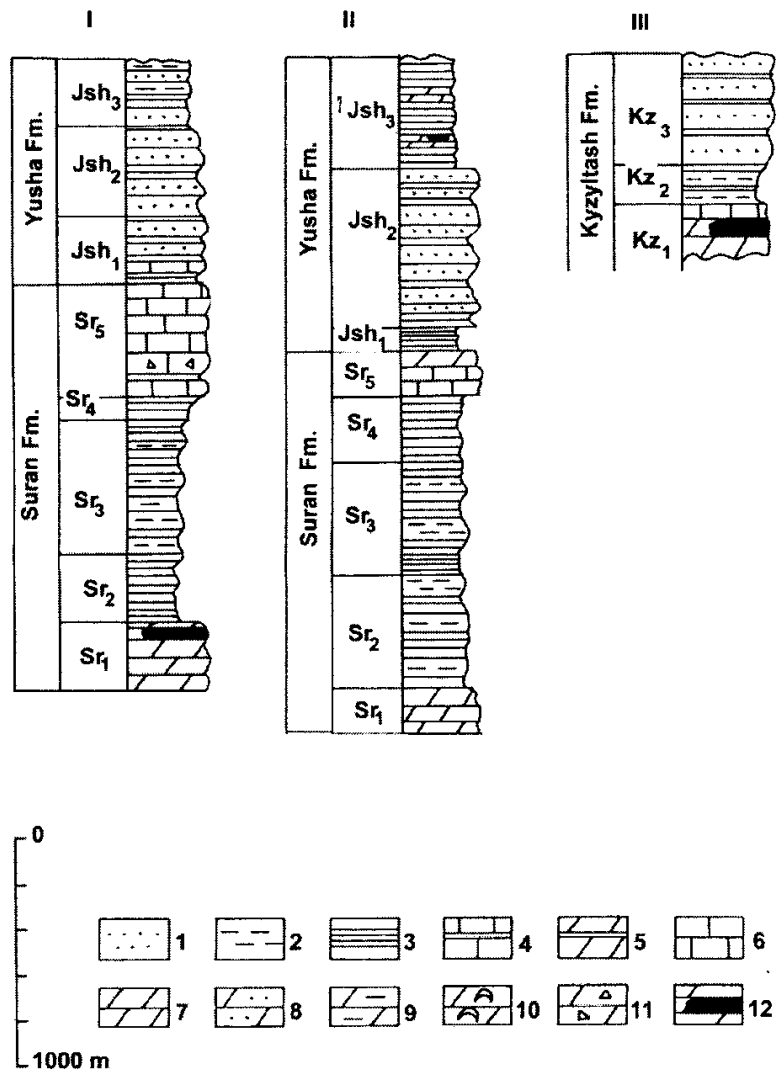

$\mathbf{N}$

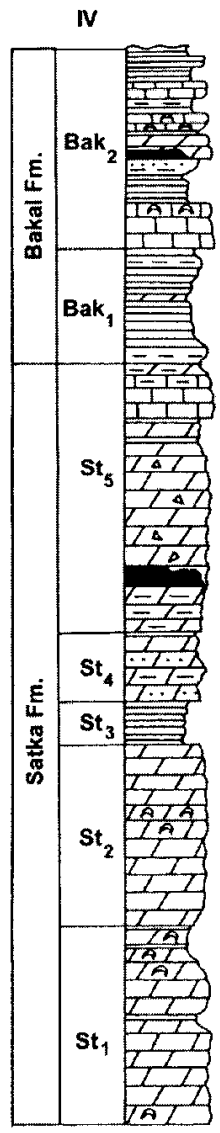

Fig. 2. a. Schematic sections of upper part Lower Riphean sequence (Suran-Satka and K y z y lt a s h - B a k a 1 stratigraphic level) 1 sandstones; 2 - siltstones; 3 - shales; 4 - alternation of limestones and shales; 5 - alternation of dolostones and shales; 6-limestones; 7 - dolostones; 8 - sandy dolostones; 9 - clayey dolostones; 10 stromatolite dolostones; 11 - brecciated dolostones; 12 - magnesites. I - Ismakaevo district; II - northern part of Ismakaevo district; III Surunzyak district; IV Satka district.

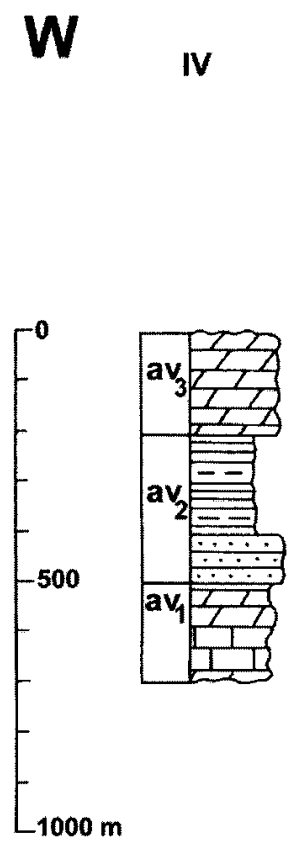

II
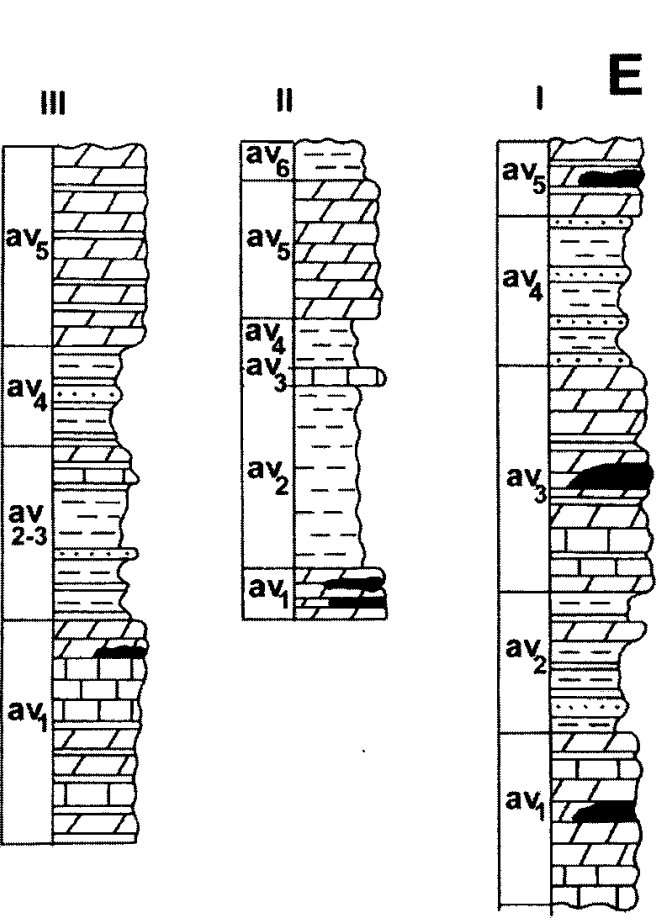

$b$

Fig. 2. b. Schematic sections of upper part Middle Riphean sequence (Avzyan fm.) I Zlatoust district; II - Beloretsk district; III - Katav-Ivanovsk district; IV - western part of Satka district. 
conditions (Maslov et al. 1999). The Upper Precambrian sedimentary sequence was folded and thrusted by some stages of tectonic activity and the modern structure of BMA consists of different synclinoriums and anticlinoriums. The main tectonic stages were Cadomian and Variscan. Generally sedimentary rocks are affected by burial epigenesis in the western and central part of BMA and greenschists/amphibolites in the eastern part of the megastructure. Sparry magnesite deposits (SMD) are located in the dolostones of the LR and MR series and are absent in the dolostones units of the Upper Riphean.

All SMD are located in different parts of the modern tectonic structure (different anticlines and synclines) and have no control of folds, faults and thrusts. As a rule, ore bodies have layer-like shape and are folded together with country rocks. There are very rare intrusive massifs in the BMA and some generations of diabase dykes, which have regional spreading. As it was shown for LR SMD diabase is younger than magnesite with the presence of contact metamorphic aureoles of dolomite marble and brusite. In the Bakal ore field a small time window (about $70 \mathrm{Ma}$ ) is found, for the formation of the magnesites between the litification of the carbonate rocks and the intrusion of the diabase dykes (Krupenin $\&$ Ellmies 2001). SMD are not connected with the stages of metamorphism. The deposits are located in several parts of BMA with different alterations of host rocks. There occurs burial epigenesis in the central part, greenschist and amphibolite metamorphism in the eastern part of BMA.

\section{Stratigraphic intervals of SMD}

There are some stratigraphic levels of SMD placed in the Lower Riphean sequence (Fig 2a). Ismakaevo and Kardon deposits (southern part of BMA) which are located in lower part of Suran fm. In the central part of structure there is the Surunzyak group of SMD with large Kyzyltash deposit and some others. These deposits lie in the dolostones of Kyzyltash $\mathrm{fm}$. concluding Lower Riphean sequence in this part of BMA. There are two levels of magnesite mineralization in the northern part of BMA. Satka group is located in the upper part of Satka fm. (stratigraphic equivalent of Suran fm.). The Bakal group of deposits exists in upper unit of Bakal fm. (stratigraphic equivalent of Kyzyltash fm.). Most of SMD lie in widespread dolostone horizons with thickness from 50-60 m (Shuidin horizon of Bakal fm.) to 500-750 m (Karagay horizon of Satka fm.). As a rule limestones overlie magnesite-bearing dolomite horizons.

SMD of MR are located in Avzyan fm. finishing Middle Riphean sequence. Large groups of deposits (Zlatoust and Beloretsk) are concentrated in the eastern part of BMA, some small ones - in the center and only single occurrences are in the western part. Most deposits occur in the lower carbonate member (Kataskin) of Avzyan fm. Only the largest Semibratskoe deposit from Zlatoust group has magnesite bodies on three carbonate levels. In comparison with LR deposits country carbonates of MR SMD, which are represented by dolostones and dolomitized limestones. Stratigraphic dolostone horizons are absent (Fig. 2 b). The Kataskin member is composed of light-grey, pink and green-grey dolostones, sometimes with lenses of cherts, interbanded with limestones and green-grey and red shales. There were found euhedron gypsum in fine-grained dolomites and $\mathrm{Mg}$-chlorite in red shales of the Kataskin member in the western part of BMA (Krupenin et al. 2002). It is the first find of gipsum in the Urals Riphean sequence. This find with other mineralogical and geochemical peculiarities can be an indicator of evaporitic conditions of the Kataskin time of Middle Riphean.

\section{Ore body characteristic}

The shape of LR magnesite body occurrences is very often layer-like, sometimes lens-like. In the quite well investigated Satka ore field the majority of the deposits has a thickness from 13 to $29 \mathrm{~m}$ with lengths along the strike from 500 to $1500 \mathrm{~m}$ and lengths along the dip from 350 to $800 \mathrm{~m}$. The largest ore body of Satka deposit has thickness up to $45 \mathrm{~m}$ with length along the strike about $5 \mathrm{~km}$ and along the dip to $2 \mathrm{~km}$ (Anfimov et al. 1983). As a rule ratio of thickness and extension of magnesite bodies is about 1:100 for different deposits. Only for Ismakaevo this ratio is about 1:10. It is possible the existence of 2-3 ore bodies in one section.

The shape of MR magnesite deposits is predominantly lens-like. There can be some ore bodies in one section. For example, in Katav-Ivanovsk deposit there were investigated 5 bodies with thickness of 1-3 m into dolostone and dolomitized limestone sequence (Krupenin 2001). Thickness of different occurrences varies from some meters (Katav-Ivanovsk, Yaru) to 40-50 m (Otnurok, 
Semibratskoe). The spreading of ore bodies along the strike varies from $100-200 \mathrm{~m}$ to $500-1100 \mathrm{~m}$.

The contacts of LR ore bodies are sharp. It is easy to distinguish corse-grained magnesite and fine-grained host dolomite. Lateral contacts as a rule are discordant and cut sedimentary bedding or stromatolite texture. Sometimes it is possible to trace the bedding in country dolostones to banded magnesites. Investigation of the main ore body shape in Satka deposit (Karagay quarry) shows gradual pinching out similarly to sedimentary layers. There are specific structures of diagenetic breccia in the host dolomites of some SMD. The breccia consists of lightly rotated clasts with relicts of sedimentary bedding in grey recrystallized dolomite mud. This structure is accompanied by nests of corse-grained white dolomite with euhedron quartz. Zones of such breccia with complicated body shape can reach a thickness of $20 \mathrm{~m}$ in Satka deposit.

The contacts of MR ore bodies with host dolomites are complicated and developed within different sedimentary structures (massive, bedding, stromatolites). Very often ore bodies have a zone of the impregnations of magnesites in host dolomites. It is the characteristic feature of different MR occurrences. In the Semibratskoe deposit, during exploration with trial drilling, it was distinguished zones of impregnable magnesites (magnesite-bearing dolomite) near magnesite bodies with thickness ranging from 5 to 30 $m$ (Krupenin 2001). As the size of disseminated magnesite crystalls is not distinguished so well from the size of country dolomites sometimes only chemical analysis allows drawing the boundaries of the ore body.

\section{Magnesite characteristic}

The crystall structures of LR magnesites are typically corse-grained with size of crystalls from 2-5 (close-grained) to 50-150 mm (corse-grained, Fig. 3 a). Very often average size of crystalls is about $10-30 \mathrm{~mm}$. This size does not depend upon metamorphic alterations, because it is the same in Satka group (burial epigenesis) and Surunzyak group (epidote-amphibolite stage). Textures of magnesite vary from massive, banded to nest-banded and pinolitic. The last kind of texture is connected with clay-carbonaceous admixture. Sometimes more corse-grained magnesite is developed in the contact parts of the ore bodies.

The crystall structures of MR magnesites are remarkable characteristic features. Size of magnesite crystalls varies from 1 to $3 \mathrm{~mm}$, with the maximum size of $5 \mathrm{~mm}$ (Fig. $3 \mathrm{~b}$ ). Larger size of magnesite crystalls is rather rare. This particular feature does not depend upon metamorphic alterations. The same grained structure is characteristic of SMD in zone of burial epigenesis (Yaru, Katav-Ivanovsk), greenschists (Semibratskoe) or amphibolites (Beloretsk group).

The mineral composition of LR magnesite ores is simple and contains about 95-99\% of magnesite. Admixtures are represented by quarz, dolomite, $\mathrm{Mg}$-chlorite (pennine), pyrite, disseminated carbonaceous (shungite), talc, very rare calcite little veins, clastic biotite, apatite and rutile. Talc is famous in different deposits as small lenses and nests in the contact parts of ore bodies. In the country dolomites all these mineral-admixtures are present too, and additionally mica and hydromica can be found.

The chemical composition of LR magnesites has some variations. Magnesites of the Satka group with 45,646,2 wt. $\% \mathrm{MgO}$ are of the best quality. Concentrations of $\mathrm{CaO}, \mathrm{FeO}$ and $\mathrm{SiO}_{2}$ range about 1 wt. $\%, \mathrm{Al}_{2} \mathrm{O}_{3}$ - about 0,3 wt.\%. For other deposits are typical higher contents

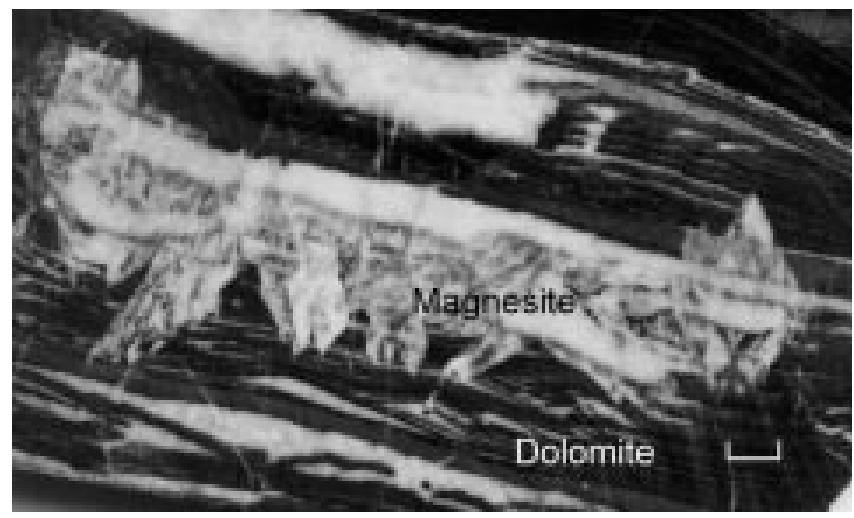

Fig. 3. a. Corse-grained magnesite in bedding fine-grained dolomite. Satka deposit. Scale is $1 \mathrm{~cm}$.

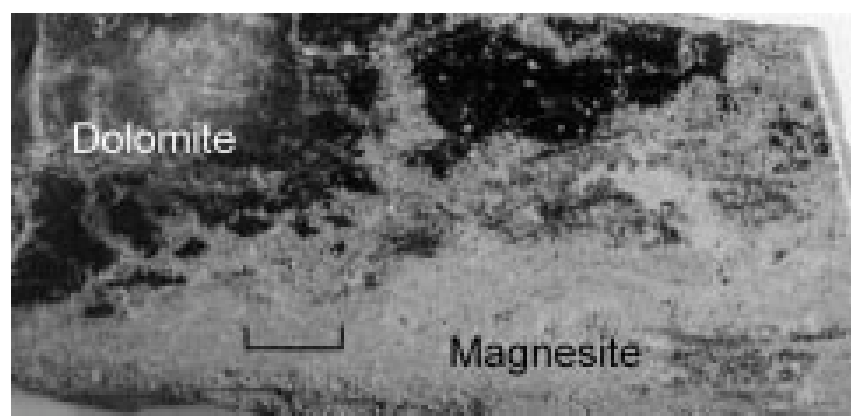

Fig. 3. b. Close-grained magnesite in bedding fine-grained dolomite. Katav-Ivanovsk deposit. Scale is $1 \mathrm{~cm}$. 
Table 1: Average chemical composition of sparry magnesites from the Urals Riphean deposits

\begin{tabular}{|c|c|c|c|c|c|c|c|c|c|c|c|c|c|c|c|}
\hline & Deposit & $\mathrm{N}$ & $\mathrm{SiO}_{2}$ & $\mathrm{TiO}_{2}$ & $\mathrm{Al}_{2} \mathrm{O}_{3}$ & $\mathrm{Fe}_{2} \mathrm{O}_{3}$ & $\mathrm{FeO}$ & $\mathrm{MnO}$ & $\mathrm{MgO}$ & $\mathrm{CaO}$ & $\mathrm{Na}_{2} \mathrm{O}$ & $\mathrm{K}_{2} \mathrm{O}$ & $\mathrm{LOI}$ & $\mathrm{P}_{2} \mathrm{O}_{5}$ & $S$ \\
\hline 1 & Satka** & 110 & 1,0 & 0,01 & 0,3 & 0,2 & 0,6 & 0,03 & 46,0 & 0,8 & 0,04 & 0,02 & 50,8 & 0,01 & 0,1 \\
\hline 2 & Ismakaevo** & 144 & 5,1 & & 0,5 & $2,2^{*}$ & & & 43,3 & 0,9 & & & 46,7 & & \\
\hline 3 & Bakal & 4 & 0,42 & & 0,14 & 0,57 & 3,73 & 0,03 & 40,49 & 5,33 & & & 49,69 & 0,13 & \\
\hline 4 & Kyzyltash & 4 & 1,37 & 0,02 & 0,41 & 0,64 & 1,53 & 0,05 & 44,13 & 0,56 & 0,05 & 0,05 & 50,21 & 0,01 & \\
\hline 5 & Semibratskoe ${ }^{\star *}$ & 22 & 1,5 & 0,03 & 0,3 & 0,3 & 1,8 & 0,08 & 44,5 & 1,1 & 0,06 & 0,07 & 49,9 & 0,04 & 0,1 \\
\hline 6 & Semibrats & 23 & 0,9 & 0,03 & 0,3 & 1 & 5 & 0,14 & 41,6 & 1,6 & 0,05 & 0,06 & 49 & 0,04 & 0,11 \\
\hline 7 & Katav-Ivanovsk & 4 & 5,68 & & 0,29 & 1,33 & 1,85 & 0,09 & 38,12 & 4,34 & 0,05 & 0,12 & 46,90 & 0,02 & \\
\hline 8 & Egorova Polyana & 1 & 8,54 & 0,03 & 0,78 & $1,94^{*}$ & & 0,04 & 43,96 & 0,49 & 0,06 & 0,02 & 46,18 & 0,02 & \\
\hline 9 & Katayka & 1 & 4,57 & 0,03 & 0,82 & 2,34 & & 0,02 & 40,02 & 0,16 & 0,10 & 0,13 & 49,94 & 0,01 & 0,04 \\
\hline
\end{tabular}

Comments: $\mathrm{N}$ - quantity of samples; $*-\mathrm{Fe}_{2} \mathrm{O}_{3}+\mathrm{FeO} ; * *$ - after (Main magnesite ..., 1993).

of following constituents (Table 1, lines 2-4): $\mathrm{SiO}_{2}(1,1-$ 5,3 wt.\%), $\mathrm{FeO}\left(1,5-3,2\right.$ wt.\%), $\mathrm{Al}_{2} \mathrm{O}_{3}(0,6-2,13$ wt. \%) and $\mathrm{CaO}(1,1-5,3$ wt.\%). Concentrations of minor elements in magnesites have strong resemblance with the ones in country dolomites (Anfimov et al., 1983; Ellmies et al., 1999) without enrichment with elementindicators of magmatic rocks. REE distributions of chondrite normalized LR magnesites are always distinguished from country dolomites by depletion of LREE. It is a result of mineralogical control. Additional fractionation and decrease of LREE is connected to metasomatic recrystallization (Moeller 1989), because more quantity of fluids has passed throgh such zones (Fig. 4a). So in more corse-grained magnesites further decrease of LREE and increase of HREE can be observed. A small negative Eu anomaly confirms lowtemperature process of magnesite formation. Magnesite $\left(\delta^{18} \mathrm{O}+15 \% \circ\right)$ is depleted in ${ }^{18} \mathrm{O}$ compared to dolomite $\left(\delta^{18} \mathrm{O}+20 \%\right.$ ) in Satka deposit. This can reflect the influence of meteoric water in the source of the $\mathrm{Mg}$ bearing fluids. The $\delta^{13} \mathrm{C}$-values are with 2 to $+2 \%$ osimilar in magnesite and dolomite (Krupenin \& Ellmies 2001).

The mineral composition of MR magnesite ores is very similar to the LR one. Main admixtures for magnesite are quarz, dolomite, $\mathrm{Mg}$-chlorite, calcite. The chemical composition of the magnesite ore shows increase on $\mathrm{SiO}_{2}(1,5-8 \mathrm{wt} . \%), \mathrm{Al}_{2} \mathrm{O}_{3}(0,3-0,8 \mathrm{wt} . \%)$ and $\mathrm{FeO}(1,8-5 \mathrm{wt} . \%)$ in comparison with the LR magnesites (Table 1, lines 5-9). Sometimes ore bodies contain breinerite with FeO 10-11 wt.\% (Katav-Ivanovsk, Kuzha group). Breinerite from Katav-Ivanovsk has $\mathrm{FeO}$ to 15 mol.\% (microproba analysis). There is a kind of magnesite with relatively lower contents of $\mathrm{SiO}_{2}(0,9$ wt. \%) and $\mathrm{Al}_{2} \mathrm{O}_{3}(0,3 \mathrm{wt} . \%)$, but higher ones of $\mathrm{FeO}(5$ wt.\%) in the Semibratskoe deposit (Table 1, line 6). It is known that magnesites from different SMD in the world have higher contents of $\mathrm{FeO}$ in comparison to their host

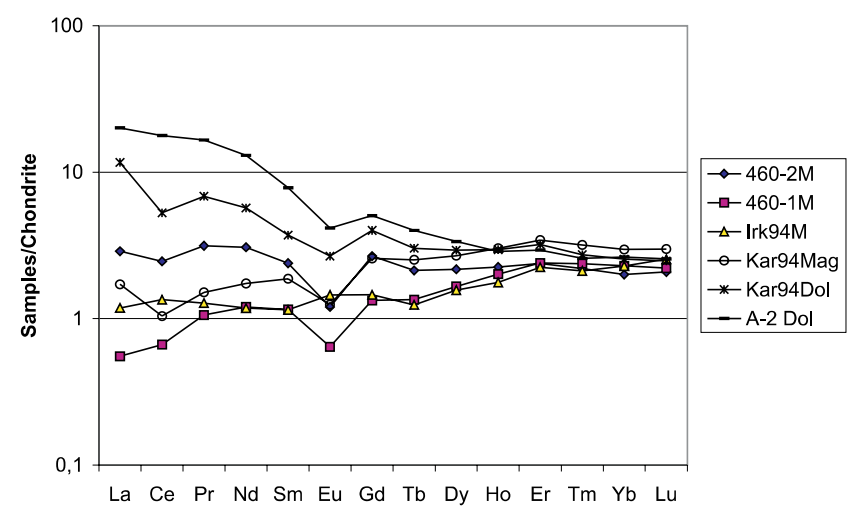

Fig. 4. a: REE distributions of LR sparry magnesites: 460-2 - Satka, Stepnoy quarry, magnesite grey close-grained; 460-1 - Satka, Stepnoy quarry, magnesite white corse-grained; Irk94M - Bakal, Irkuskan quarry magnesit grey corse-grained; Kar94Mag - Satka, Karagay quarry, magnesite grey corse-grained; Kar94Dol - Satka, dolomite $5 \mathrm{~cm}$ lateral from magnesite Kar94Mag; A-2Dol - Bakal, Irkuskan quarry, dolomite $50 \mathrm{~m}$ upper magnesite.

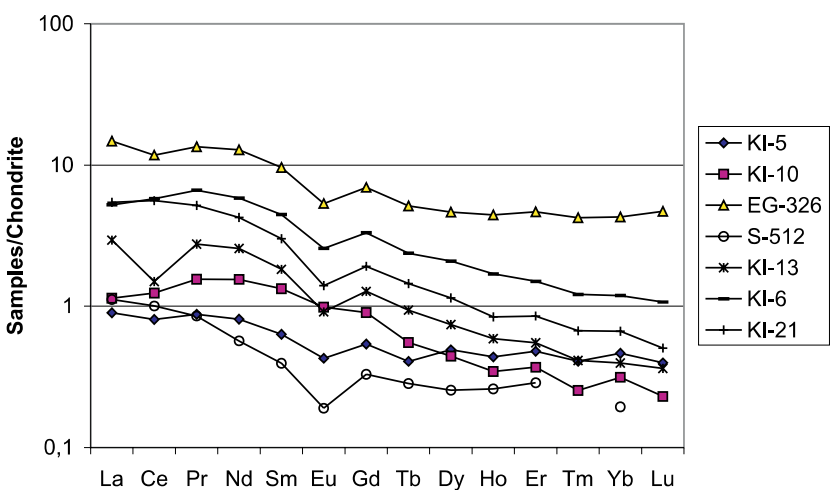

Fig. 4. b: REE distributions of MR sparry magnesites: KI-5 - KatavIvanovsk, magnesite close-grained; KI-10 - Katav-Ivanovsk, magnesite close-grained; EG-326 - Egorova Polyana, magnesite close-grained; S-512 - Semibratskoe, magnesite close-grained; KI13 - Katav-Ivanovsk, dolomite fine-grained; KI-6 - Katav-Ivanovsk, dolomite fine-grained; KI-21 - Katav-Ivanovsk, dolomite finegrained. 
dolomites. In some cases this difference can reach 3-4 times (Satka deposit), and can be nx10 times (MR deposits). Distributions of REE in MR magnesites show resemblence with ones for LR magnesites. A small distinction of the MR group is the low degree of fractionation and difference between magnesites and country dolomites (Fig. 4b). It is connected, probably, to short distance of fluid flows in magnesite bodies (absence of recrystallization?).

\section{Conclusion}

Some remarkable features of LR and MR magnesites reflect the mechanism of their origin. There is no universal or general model of SMD formation and this question is actively discussed.

We assume, that for the Lower Riphean time magnesites had been forming during early diagenesis stage, in process of host dolomite litification. This formation was connected to lateral (descended?) fluid flows through permeable dolostone horizones with partial dissolution of sedimentary carbonates and diagenetic breccia forming. Depletion of ${ }^{18} \mathrm{O}$ in magnesites confirms the influence of meteoric water on the process. Probably the source of $\mathrm{Mg}^{2+}$ for country dolomites and magnesites came from crusts of weathering of basic and ultramafic rocks (Precambrian greenstone belts) generated in humid climate in the Lower Riphean time. It is possible to suppose that sedimentary accumulations of $\mathrm{Mg}$ hydrocarbonates (kinds of hydromagnesite) could be deposited in shallow lagoon conditions. In both cases, diagenetic crystallization of magnesite in alcaline conditions and recrystallization gave long time for fluid migration and helped growing of crystall size and REE fractionation.
Magnesite occurrences in the Middle Riphean time are connected, possibly, to another source and mechanism. Probably, metasomatic fluids with high $\mathrm{Fe}$ contents were formed during kathagenesis as a result of transformation of evaporite $\mathrm{Mg}$-enriched solutions. These buried fluids came into contact with the limestones during the stage of tectonic activity and produced metasomatic replacement with the formation of magnesite and breinerite occurrences. Such model has some resemblence with the one for SMD development of the Eastern Alps (Prochaska 2000).

These speculations are based on a variety of geological and geochemical facts, but don't embrace all peculiarities of the deposits and influence of external factors. For example, it would be possible to assume a virtual possibility of penetrating of $\mathrm{Mg}$-enriched metamorphosed fluids from the eastern part of BMA and adjacent metamorphic zones of the Urals, as it was proposed for the Nothern Greywacke Zone and Spain SMD (Lugli et al. 2002). For the development of a valid model of the Riphean sparry magnesite origin it is necessary to study some additional geochemical features of ores and host carbonate rocks, which can indicate a source of fluids and their flow direction. $\mathrm{Rb}-\mathrm{Sr}$ and stable isotope geochemistry,and chemistry of halogens would be useful for investigations. We will hope, that international collaboration in the frame of IGCP project 443 will help to fulfil our knowledge of the SMD origin.

\section{Acknowledgments}

We thank prof. A.Maslov for consultations about Upper Precambrian sedimentary environments, prof. W.Prochaska and Dr. R.Ellmies for useful discussions about sparry magnesite origin and E.Musikhina for manuscript preparation. This investigation was supported by the Russian Fund of Basic Researches 00-05-64497.

\section{References}

Anfimov, L.V., Busygyn, B.D., Demina, L.E. (1983) Satkinskoe magnesite deposit (South Urals). Moscow: Nauka: 195 p. (In Russian)

Ellmies, R., Voightlaunder, G., Germann, K., Krupenin, M.T. \& P.Moeller (1999) Origin of giant stratabound deposits of magnesite and siderite in Riphean carbonate rocks of the Bashkir mega-anticline, western Urals // Geologische Rundschau, 87. P. 589-602.
Krupenin, M.T. (2001) Minerageny of Riphean sedimentary sequences//Riphean of the Urals western slope (classic sections, sedimento- and lithogenesis, minerageny, geological sights). Vol. 1. Yekaterinburg: Institute of Geology and Geochemistry, Urals Brunch. P. 124-245. (In Russian)

Krupenin M.T., Ellmies R. (2001) Genetic features of sparry magnesite in Proterozoic carbonate rocks of the South Urals// Mineral deposits at the begining of the 21-st century. Piestrzynski 
et al.(Eds). Lisse: Balkema. Swets and Zeitlinger Publishers. P. 997-999.

Krupenin, M.T., Larionov, N.N., Gulyaeva, T.Y., Demchuk I.G. (2002) New data about of sedimentary peculiarities in Avzyan time basins (Middle Riphean)//Ezhegodnik-2001, Institute of Geology and Geochemistry, Urals Brunch. Yekaterinburg. P. 43-49. (In Russian)

Lugli, S., Morteani G., Blamart D. (2002) Petrographic, REE, fluid inclusion and stable isotope study of magnesite from the Upper Triassic Burano Evaporites (Secchia valley, northern Apennines): contributions from sedimentary, hydrothermal and metasomatic sources//Mineralium Deposita, 37: 480-494.

Main magnesite deposits (1993) // Urasina, L.P., Drugaleva, T.A,
Smolin, P.P. Moscow: Nauka. 157 p. (In Russian)

Maslov, A.V., Gareev, E.Z., Krupenin, M.T., Demchuk, I.G. (1999) Fine Aluminosilicate Clastic in the Upper Precambrian sequences of Bashkir anticlinorium (to reconstruction of environments). Yekaterinburg: Urals Branch of RAS, 324 p. (In Russian)

Moeller, P. (1989) Magnesite. Geology, mineralogy, geochemistry and formation of $\mathrm{Mg}$-carbonats. Monogr. Series Mineral Deposits. V.28. P. 1-307

Prochaska, W. (2000) Magnesite and talc deposits in Austria// Mineralia Slovaca, 32, 543-548.

Semikhatov M.A. (1991) General problems of Proterozoic stratigraphy in the USSR//Sov. Sci. Rev. G. Geology. V.1. 192 p. 